\title{
Editorial Comment: Ascending testis: A congenital predetermined condition
}

\author{
Nasib Alchoikani ${ }^{1}$, Khaled Ashour ${ }^{2}$ \\ ${ }^{1}$ Oxford University Hospitals NHS Foundation Trust: John Radcliffe Hospital, Department of Paediatric Surgery; ${ }^{2}$ Oxford \\ University Hospitals NHS Foundation Trust: John Radcliffe Hospital, Department of Paediatric Surgery, UK; Alexandria \\ University Hospital, Department of Paediatric Surgery, Egypt
}

J Pediatr Urol. 2021 Apr;17(2):192.e1-192.e3.

DOI: 10.1016/j.jpurol.2020.12.016 | ACCESS: 10.1016/j.jpurol.2020.12.016

Natasha T. Logsdon ${ }^{1}$, Luciano A. Favorito ${ }^{1}$

${ }^{1}$ Unidade de Pesquisa Urogenital - Universidade do Estado do Rio de Janeiro - Uerj, Rio de Janeiro, RJ, Brasil

\section{COMMENT}

In this interesting paper the authors studied the intra-operative findings of patients underwent orchidopexy for ascending testes and concluded that the patients with ascending testes seem to share similar intra-operative findings with patients who have true undescended testes. The authors show the presence of abnormal attachment of the gubernaculum and epididymal anomalies in the groups studied. The gubernaculum seems to be the most important anatomical structure in the testicular migration process, by means of contraction and shortening, thus imposing traction strength on the testis and facilitates the transition of the testis by through the inguinal canal (1). Undescended testis can be associated with several anatomical anomalies but the abnormalities in gubernaculum insertions and the presence of epididymal anomalies of disjunction and atresia are among the most common (2). During the surgery of undescended testis, specially in those with abdominal position, the knowledge of the testicular vascularization are very useful to preserver the testis $(3,4)$. This paper indicates that that ascending testis should be considered a congenital predetermined condition and during the child growth stay in a higher position. 


\section{CONFLICT OF INTEREST}

None declared.

\section{REFERENCES}

1. Favorito LA, Costa SF, Julio-Junior HR, Sampaio FJ. The importance of the gubernaculum in testicular migration during the human fetal period. Int Braz J Urol. 2014;40:722-9.

2. Favorito LA, Sampaio FJ, Javaroni V, Cardoso LE, Costa WS. Proximal insertion of gubernaculum testis in normal human fetuses and in boys with cryptorchidism. J Urol. 2000164(3 Pt 1):792-4.

3. Sampaio FJ, Favorito LA, Freitas MA, Damião R, Gouveia E. Arterial supply of the human fetal testis during its migration. $J$ Urol. 1999;161:1603-5.

4. Benzi TC, Logsdon NT, Sampaio FJB, Favorito LA. Testicular arteries anatomy applied to fowler-sthephens surgery in high undescended testis - a narrative review. Int Braz J Urol. 2022;48:8-17.

\section{Luciano A. Favorito, MD, PhD}

ARTICLE INFO

Unidade de Pesquisa Urogenital

da Universidade do Estado de Rio de Janeiro - UERJ,

Rio de Janeiro, RJ, Brasil

E-mail: lufavorito@yahoo.com.br

\begin{tabular}{r} 
ARTICLE INF0 \\
\hline (D) Luciano A. Favorito \\
http://orcid.org/0000-0003-1562-6068 \\
Int Braz J Urol. 2022; 48: 184-5
\end{tabular}

